\title{
Evaluation of Different Fungicides against Colletotrichum graminicola, the Cause of Red Leaf Spot of Sorghum
}

\author{
Misbah Ali ${ }^{1}$, Safdar Ali ${ }^{1}$, Muhammad Ahmad Zeshan ${ }^{2 *}$, Rana Binyamin ${ }^{3}$, Nadeem Ahmed ${ }^{4}$, Muhammad \\ Usman Ghani ${ }^{5}$ and Awais Ahmed Khan ${ }^{2}$
}

${ }^{1}$ Department of Plant Pathology, University of Agriculture, Faisalabad, 38000, Pakistan; ${ }^{2}$ Department of Plant Pathology, College of Agriculture, University of Sargodha, Sargodha, 40100, Pakistan; ${ }^{3}$ Department of Plant Pathology, Sub-Campus Burewala, University of Agriculture, Faisalabad, 61010, Pakistan; ${ }^{4}$ Department of Plant Pathology, Muhammad Nawaz Sharif University of Agriculture, Multan, 66000, Pakistan; Institute of Soil and Environmental Sciences, University of Agriculture, Faisalabad, 38000, Pakistan.

\begin{abstract}
Sorghum (Sorghum bicolor L. Moench) is a very important cereal crop for human beings and livestock. It is subjected to many diseases in Pakistan like fungal, bacterial, and viral among which the fungal diseases are the most destructive. Colletotrichum graminicola is the causal organism of red leaf spot of sorghum which causes heavy losses to the sorghum crop cultivated in different areas of Pakistan. It produces black anthracnose spots on all the above ground parts especially leaves. In the present study, four fungicides (Aliette, Cabrio Top, Nativo, and Melody Duo) were evaluated against C. graminicola under in-vitro and in-vivo conditions. The poisoned food technique was used for in vitro trials with three concentrations (150 ppm, 200 $\mathrm{ppm}$, and $250 \mathrm{ppm}$ ). The most effective concentration of fungicides from laboratory experiment was used in field conditions against red leaf spot of sorghum. Results showed that Cabrio Top was the most effective fungicide by showing $88 \%$ fungal inhibition while Native also exhibited good results by showing $78.1 \%$ fungal inhibition. The remaining 2 fungicides Melody Duo and Aliette were least effective by showing 48.2\% and $37.5 \%$ fungal inhibition, respectively. In vivo experiment from all four fungicides, Cabrio Top and Nativo showed best results by controlling $74.57 \%$ and $71.52 \%$, respectively disease over control while Melody Duo and Aliette were least effective by controlling $65.31 \%$ and $60.08 \%$ disease over control. It may be concluded that the Cabrio Top at $250 \mathrm{ppm}$ concentration is the best to manage red leaf spot disease severity under field conditions.

Received | June 12, 2020; Accepted | May 03, 2021; Published | July 01, 2021

*Correspondence | Muhammad Ahmad Zeshan, Department of Plant Pathology, College of Agriculture, University of Sargodha, Sargodha, 40100, Pakistan; Email: ahmd_1566@yahoo.com

Citation | Ali, M., S. Ali, M.A. Zeshan, R. Binyamin, N. Ahmed, M.U. Ghani and A.A. Khan. 2021. Evaluation of different fungicides against Colletotrichum graminicola, the cause of red leaf spot of sorghum. Pakistan Journal of Agricultural Research, 34(3): 599-607.

DOI | https://dx.doi.org/10.17582/journal.pjar/2021/34.3.599.607

Keywords | Anthracnose, Management, Fungicides, Evaluation, Systemic
\end{abstract}

\section{Introduction}

Gorghum (Sorghum bicolor L. Moench) serves as food purpose for human beings and animals. It is also useful for manufacturing of beverages which contain alcohol and some biofuels (Amelework et al., 2015). Sorghum has appreciable potential in the food and beverages market because low gluten content makes it more suitable for celiac. It contains phenolics, antioxidants and cholesterol lowering waxes, which are utilized in different industries because it is significant source of nutraceuticals (John et al., 2006). It is on the $5^{\text {th }}$ number among all cereal crops with sixty million tons of annual production in the whole world. As 
far as Pakistan is concerned, it has a cultivation area of 0.34 million hectare with the production of 0.21 million tons with $620 \mathrm{~kg} \mathrm{ha}^{-1}$ average yield (Habib et al., 2013). It is a very important crop which provides more than 85\% world's food calories (Thakur and Mathur, 2000). Sorghum plants have extremely large root-to-leaf surface area and they have capability to roll their leaves to minimize transpiration during dry environment. That's why the sorghum plants have great water management efficiency (Balota et al., 2018).

Many biotic and abiotic factors influence the yield potential of sorghum crop. Abiotic factors are temperature, rain fall, and humidity while biotic factors include the attack of different pathogens and insect pests etc. (Crouch et al., 2008). Different fungal, bacterial and viral diseases reduce the yield and quality of the sorghum crop. Colletotrichum graminicola causes red leaf spot disease in sorghum crop and heavy losses are worldwide (Acharya et al., 2019). C. graminicola attacks leaf, stem, and head of the sorghum plant (Marley et al., 2001). Red leaf spot is the most damaging disease as it interrupts with photosynthetic process which ultimately reduces the quality and quantity of the produce (Erpelding and Prom, 2004). The salient response of the plant against pathogenic attack appears in the form of necrotic and sunken lesions on leaves and stem (Silva et al., 2008) followed by dropping of leaves. Pathogenic growth is favored in warm and humid conditions (Ngugi et al., 2000) and disease progresses rapidly during anthesis and grain formation ( $\mathrm{Li}$ and TeBeest, 2009). The fungus overwinters in crop remains, seeds, and weeds (Gwary et al., 2006). The red leaf spot disease severity from $15-20 \%$ may reduce the yield upto 55\% (Tesso et al., 2012). Red leaf spot disease has been managed by different fungicides in the world (Marley, 2004). There was significant reduction in red leaf spot disease severity when sorghum seeds were treated with metalaxyl, carboxin and thiram (Gwary et al., 2008). The application of benomyl showed reduction in disease severity and increase in sorghum yield (Marley, 2004). The foliar sprays of systemic fungicides (benzimidazole and azoxystrobin) at weekly intervals resulted in minimum disease severity and maximum yield (Pinto, 2003). There are many new and old methods which are in practice for the management of this disease. There is a big research gap in Pakistan regarding the identification and management of the red leaf spot disease in sorghum.
The efficacy of fungicides with suitable concentration has not yet been studied against red leaf spot of sorghum in Pakistan. In view of all previous study this research plan having the objectives to evaluate four fungicides with three different concentrations against C. graminicola in-vitro and to evaluate the most effective concentration against red leaf spot disease under field conditions.

\section{Materials and Methods}

\section{Sample collection and preservation}

The symptomatic samples of different plant parts like leaves and stems were collected in polythene bags from the diseased field. Samples were stored at $-4^{\circ} \mathrm{C}$ until further processing in Plant Virology Lab, Department of Plant Pathology, University of Agriculture Faisalabad.

\section{Preparation of PDA culture medium}

Two fifty grams of potatoes were taken, peeled and cut into pieces. Potatoes were boiled in water for making potato starch. Starch was collected by staining the potatoes boiled in water. Starch containing potato extract was poured in a flask and $20 \mathrm{~g}$ glucose was dissolved in it. The final volume taken was $500 \mathrm{~mL}$. Another flask was taken and $500 \mathrm{ml}$ distilled water was added in it. Twenty gram of Agar Agar was dissolved in flask containing $500 \mathrm{ml}$ distilled water. The both solutions were mixed together to make final volume $1000 \mathrm{ml}$ and autoclaved at $121^{\circ} \mathrm{C}$ and $15 \mathrm{psi}$ for 15-20 minutes.

\section{Isolation of pathogen}

For the isolation and identification of pathogen infected samples of red leaf spot of sorghum were cut into small pieces of $3-5 \mathrm{~mm}$. Samples bits were washed with tap water and then surface sterilized with 5\% Sodium Hypochlorite solution for 10 seconds followed by 3 consecutive washings with distilled water. After washing bits were put into the tissue paper for drying.

PDA media was poured into the petri plates. When media was solidified, sample bits were placed into the petri plates containing media. Plates were incubated at $26 \pm 2{ }^{\circ} \mathrm{C}$ temperature for 2-3 days. Spourlation of fungus was seen from these bits.

\section{Identification}

The fungus was identified with the help of compound 
microscope present in the laboratory. Single spore method was adopted for purification of the fungus. Single hyphe of mycelium was picked from the sporulation and placed into another petri plate containing PDA media and incubated the plate as above mentioned. After 3-4 days pure sporulation of our required fungus was observed from this plate.

\section{In-vitro evaluation of fungicides against the} Colletotrichum graminicola

Poisoned food technique: In-vitro evaluation of four fungicides (Cabrio Top, Nativo, Melody Duo, Aliette) with three concentrations (150 ppm, $200 \mathrm{ppm}$ and $250 \mathrm{ppm}$ ) were done to find out the most efficient fungicide against C. graminicola. The concentration was made by dissolving $1 \mathrm{~g}$ of fungicide in $1000 \mathrm{ml}$ of water for 1000 ppm solution. For making 150 ppm concentration, $1.5 \mathrm{ml}$ was taken from 1000 ppm solution and dissolved in $100 \mathrm{ml}$ of PDA media. Concentration of 200 ppm was made by adding $2 \mathrm{ml}$ from $1000 \mathrm{ml}$ fungicide solution into $100 \mathrm{ml}$ of PDA media. Similarly, for making 250 ppm concentration, $2.5 \mathrm{ml}$ from $1000 \mathrm{ppm}$ of fungicide solutions was taken and dissolved in $100 \mathrm{ml}$ of PDA media.

Fungicides with different concentrations were added in the PDA solution at little bit warm stage stirred well for proper mixing of fungicide in the agar solution. Media containing fungicides was poured into the sterilized petri plates under hygienic conditions. Agar disc of $5 \mathrm{~mm}$ of pathogen culture was put at the center of petri plate containing media having fungicides. Plates were wrapped with para film and incubated at optimum temperature.

Data of mycelial growth inhibition: The data of the mycelial growth inhibition was recorded by this formula:

$\%$ inhibition $=\frac{\text { Mycelial growth in control }- \text { Mycelial growth in treated }}{\text { Mycelial growth in control }} \times 100$

Data of mycelial sporulation was recorded after 48 , 72 and 94 hours of incubation and compared with the control. The most effective concentration of fungicides was further used for evaluation in the field.

\section{In-vivo evaluation of fungicides}

Experimental material and layout: Seeds of five varieties and pure lines of sorghum i.e. (Hegari, Sodaan, Kelaash, JS-263 and FS-32015) were collected from Fodder Research Institute, Ayub Agricultural Research Institute (AARI), Faisalabad. All the genotypes were sown in research area Department of Plant Pathology, University of Agriculture Faisalabad under randomized complete block design (RCBD) by maintaining $\mathrm{R} \times \mathrm{R} 45.72 \mathrm{~cm}$ and $\mathrm{P} \times \mathrm{P} 30.45 \mathrm{~cm}$ distance.

\section{Table 1: Disease rating scale.}

$\begin{array}{lll}\text { Score } & \text { Infection } & \text { Response } \\ 1 & \text { No lesions } & \text { Immune } \\ 2 & 1-5 \% & \text { Highly resistant } \\ 3 & 6-10 \% & \text { Moderately resistant } \\ 4 & 11-20 \% & \text { Slightly resistant } \\ 5 & 21-30 \% & \text { Slightly susceptible } \\ 6 & 31-40 \% & \text { Moderately susceptible } \\ 7 & 41-50 \% & \text { Susceptible } \\ 8 & \geq 75 \% & \text { Highly susceptible }\end{array}$

\section{Application of fungicides}

The fungicides which were previously tested in laboratory experiment were sprayed in the field with their most effective concentration. Three consecutive applications of spray were done with 15 days interval. Details of the fungicides are given in Table 2.

\section{Table 2: Details of the fungicides used against red leaf} spot disease.

\begin{tabular}{|c|c|c|c|}
\hline $\begin{array}{l}\text { Commer- } \\
\text { cial name }\end{array}$ & $\begin{array}{l}\text { Manufac- } \\
\text { turer }\end{array}$ & Form & Active ingredient \\
\hline Aliette & $\begin{array}{l}\text { Bayer } \\
\text { Pakistan }\end{array}$ & $\begin{array}{l}80 \% \mathrm{WP} \text { (Wet } \\
\text { able powder) }\end{array}$ & Fosetyl-Al \\
\hline Cabrio Top & $\begin{array}{l}\text { FMC } \\
\text { Pakistan }\end{array}$ & $\begin{array}{l}60 \text { WDG (Water } \\
\text { Dispersible } \\
\text { Granule) }\end{array}$ & $\begin{array}{l}\text { Pyraclostrobin 5\%, } \\
\text { Metiram 55\% }\end{array}$ \\
\hline Nativo & $\begin{array}{l}\text { Bayer } \\
\text { Pakistan }\end{array}$ & $75 \% \mathrm{WG}$ & Trifloxystrobin \\
\hline $\begin{array}{l}\text { Melody } \\
\text { Duo }\end{array}$ & $\begin{array}{l}\text { Bayer } \\
\text { Pakistan }\end{array}$ & $69 \% \mathrm{WG}$ & $\begin{array}{l}\text { Iprovalicarb } \\
\text { propineb }\end{array}$ \\
\hline
\end{tabular}

\section{Data of disease severity}

Data of disease severity was recorded after 7 days of each spray and compared with control. Data of disease severity was calculated with the help of this formula.

$$
\text { Disease severity }=\frac{\text { Number of infected leaves }}{\text { Number of Total leaves }} \times 100
$$

The genotypes were categorized by using this disease rating scale (Mishra, 2005). 
The efficacy of the fungicides was calculated as follows.

$\%$ Efficacy $=\frac{\text { Disease severity in control }- \text { disease severity in treated }}{\text { Disease severity in control }} \times 100$

\section{Statistical analysis}

The recorded data was analyzed through Analysis of Variance (ANOVA) and treatments means were compared by Least Significant Difference (LSD) test at 5\%. Data was analyzed by Statistix 8.1 (Steel et al., 1997).

\section{Results and Discussion}

In-vitro evaluation of different fungicides against red leaf spot of sorghum

The ANOVA showed that all the fungicides significantly reduced the mycelial growth of $C$. graminicola under in-vitro conditions (Table 3). There was significant difference between all the concentrations in inhibiting the mycelia growth. The minimum mycelia growth was recorded after 48 hours while maximum after 96 hours of incubation.

Table 3: Efficacy of fungicides against red leaf spot disease

$\begin{array}{llll}\text { Fungicides } & \begin{array}{l}\text { Disease } \\ \text { incidence (\%) } \\ \text { before spray }\end{array} & \begin{array}{l}\text { Disease inci- } \\ \text { dence (\%) after } \\ \text { spray }\end{array} & \begin{array}{l}\text { Efficacy } \\ \text { (\%) }\end{array} \\ \text { Aliette } & 53.28 & 18.48 & 65.31 \mathrm{c} \\ \text { Nativo } & 51.69 & 14.72 & 71.52 \mathrm{~b} \\ \text { Melody Duo } & 55.97 & 22.34 & 60.08 \mathrm{~d} \\ \text { Cabrio Top } & 50.92 & 12.95 & 74.57 \mathrm{a}\end{array}$

$L S D=0.77$ Mean values with similar letters in same column are non-significant with each other at $5 \%$ probability level.

The fungicides (Aliette, Cabrio Top and Nativo and Melody Duo) were tested against $C$. graminicola in the laboratory by using poisoned food technique with three concentrations (150 ppm, $200 \mathrm{ppm}$ and 250 $\mathrm{ppm})$. Data of fungal mycelial growth of fungus was recorded after 48, 72, and 96 hours which showed that Cabrio Top and Nativo were the most effective as compared to the Aliette and Melody Duo. The most effective concentration was $250 \mathrm{ppm}$ in all the fungicides (Figure 1).

In-vivo evaluation of fungicides for the management of red leaf spot of sorghum disease

The individual effect of all the treatments is significant in reducing red leaf spot disease in all the varieties.
The two ways interaction of treatments and varieties is also significant. There was significant reduction in disease severity after each consecutive spray.

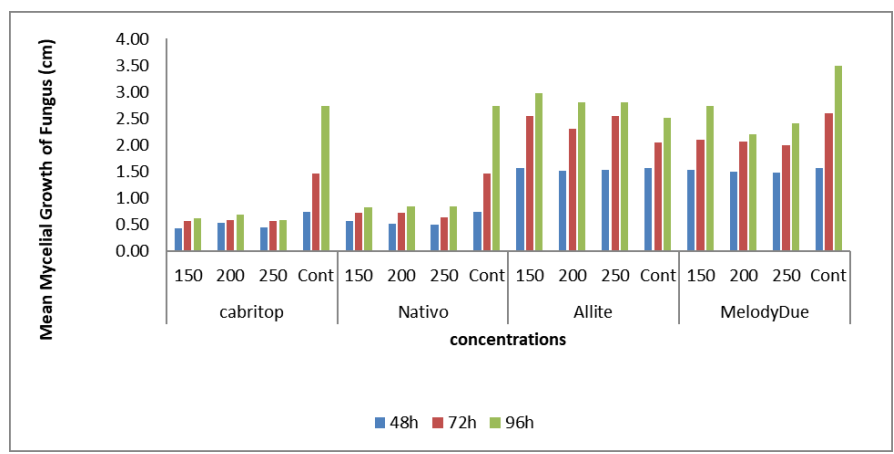

Figure 1: Graphical representation of Mycelial growth of C. graminicola spp. after 48, 72 and 96 hours at 150 ppm, 200 ppm and 250 ppm concentrations.

Table 4: Effect of fungicides on red leaf spot disease after repeated sprays.

$\begin{array}{llll}\text { Treatments } & \mathbf{1}^{\text {st }} \text { Spray } & \text { 2 }^{\text {nd }} \text { Spray } & \text { 3 }^{\text {rd }} \text { Spray } \\ \text { Aliette } & 25.34 \mathrm{c} & 23.81 \mathrm{c} & 21.52 \mathrm{c} \\ \text { Nativo } & 20.56 \mathrm{~d} & 18.09 \mathrm{~d} & 17.38 \mathrm{~d} \\ \text { Melody Duo } & 33.13 \mathrm{~b} & 30.08 \mathrm{~b} & 27.45 \mathrm{~b} \\ \text { Cabrio Top } & 15.89 \mathrm{e} & 13.43 \mathrm{e} & 11.24 \mathrm{e} \\ \text { Control } & 52.13 \mathrm{a} & 51.45 \mathrm{a} & 54.76 \mathrm{a} \\ \text { Mean } & 29.41 & 27.37 & 26.47\end{array}$

$L S D=0.89$ Mean values with similar letters in same column are non-significant with each other at $5 \%$ probability level.

All the fungicides significantly reduced the disease severity as compared with control (Table 5). The comparative evaluation of all fungicides showed significant difference in managing red leaf spot disease. Cabrio Top was the most effective with $74.57 \%$ efficacy followed by Nativo (71.52\%), Aliette (65.31\%) and Melody Duo (60.08\%), respectively (Table 3).

Table 5: Impact of fungicides on red leaf spot disease in all genotypes.

$\begin{array}{lllllll}\text { Fungicides } & \text { Hegari Sodaan } & \text { Kelaash JS-263 } & \text { FS-32015 } \\ \text { Aliette } & 44.81 \text { c } & 42.33 \text { c } & 39.25 \text { c } & 44.72 \text { c } & 43.15 \text { c } \\ \text { Nativo } & 39.74 \text { d } 36.23 \text { d } & 34.58 \text { d } & 39.84 \text { d } & 38.01 \text { d } \\ \text { Melody Duo } & 48.17 \text { b } & 46.92 \text { b } & 44.07 \text { b } & 49.23 \text { b } & 47.83 \text { b } \\ \text { Cabrio Top } & 33.91 \text { e } & 31.39 \text { e } & 28.04 \text { e } & 33.78 \text { e } & 32.63 \text { e } \\ \text { Control } & 54.92 \text { a } & 56.89 \text { a } & 51.74 \text { a } & 53.29 \text { a } & 52.08 \text { a } \\ \text { Mean } & 44.31 & 42.75 & 39.54 & 44.17 & 42.74\end{array}$

$L S D=0.64$ Mean values with similar letters in same column are non-significant with each other at $5 \%$ probability level. 
The recorded data described that there was significant difference in disease severity after each spray of all the fungicides (Table 4). There was obvious difference in overall disease severity after first and third spray. There was $29.41 \%$ mean disease severity after first spray which reduced to $27.37 \%$ after second and $26.47 \%$ after third spray.

The mean disease severity significantly reduced in all cultivars i.e., Hegari, Sodaan, Kelaash, JS-263 and FS-32015 (Table 5). Minimum disease severity was depicted by variety (Kelaash) in all the fungicidal applications. In varietal comparison $39.54,42.74$, 42.75, 44.17 and 44.31\% mean disease severity was recorded in Kelaash, FS-32015, Sodaan, JS-263 and Hegari, respectively.

In the present study, effect of different fungicides was tested against red leaf spot of sorghum disease caused by Colletotrichum graminicola under in vitro condition. Four different fungicides (Cabrio Top, Nativo, Melody Duo and Aliette) were evaluated after 48, 72 and 96 hours at three different concentrations (150 ppm, 200 ppm, $250 \mathrm{ppm}$ ) in the comparison with control. The concentration $250 \mathrm{ppm}$ proved more effective in all the fungicides.

In vitro trial results showed that Cabrio Top was most effective fungicide by showing $88 \%$ fungal inhibition while native also showed good results by showing $78.1 \%$ fungal inhibition. But remaining 2 fungicides Melody Duo and Aliette were least effective by showing $48.2 \%$ and $37.5 \%$ fungal inhibition respectively.

The fungicides which showed best results in the in vitro experiment were further used in the field to check the most effective fungicide against the pathogen. When the disease appeared in the field application of fungicides was done. Three sprays of each fungicide was done in the field after interval of 15 days in each spray. Data of disease severity was recorded after each spray. From all four fungicides Cabrio Top and Nativo showed best results by controlling $74.57 \%$ and 71.52\%, respectively while Melody Duo and Aliette were least effective by controlling $65.31 \%$ and $60.08 \%$ disease over control.

The most effective fungicide was Cabrio Top under invitro and in-vivo conditions. It contain pyraclostrobin and metiram which increase pathogenesis related proteins (PR-Proteins) against the pathogenic attack (Herms et al., 2002). Pyraclsotrobin boosts up the growth of the plant when applied on leaves (Swoboda and Pedersen, 2009). As the symptoms of red leaf spot are more prominent on the leaves which results in minimum photosynthesis and ultimately poor yield. The application of pyraclostrobin affects the metabolic reactions and hormonal balance in plants that manages the yield losses caused by low photosynthesis (Kanungo and Joshi, 2014). It enhances the activities of antioxidative enzymes which help the treated plants in managing the losses incited by pathogenic stress (Brodribb and Holbrook, 2004). The main symptoms of red leaf spot appear on leaves which result in reduced rate of photosynthesis by deteriorating chlorophyll formation. In current study, Cabrio Top fungicide which has pyraclostrobin as its major active ingredient gave maximum disease protection. These findings have been proved in various studies that pyraclostrobin reduces the loss of chlorophyll (Grossmann and Retzlaff, 1997). The plants applied with foliar sprays of pyraclostrobin showed increased photosynthetic rate and leaf area (Bertelsen et al., 2001). The use of fungicides containing pyraclostrobin during anthesis stage enhanced the photosynthetic process that leads in easy management of the losses caused by fungal pathogen (Fagan et al., 2010). Pyraclostrobin inhibits the fungal growth by blocking the movement of electrons in mitochondria (Balba, 2007). The depleted chlorophyll in diseased plants is repaired by the enhanced quantity of nitrate reductase enzyme due to the foliar application of fungicides having pyraclostrobin (Lima et al., 2012). The fungicide pyraclostrobin stimulates the carotenoid formation and subsequently more chlorophyll as compared to untreated plants (Logan et al., 2007). The single foliar spray of Pyraclostrobin and fluxapyroxad at anthesis, reduced red leaf disease incidence and increased yield (Acharya et al., 2019).

Under in-vitro conditions, Cabrio Top inhibited the mycelia growth more effectively than other fungicides. Metiram and Pyraraclostrobin treated petri plates showed minimum sporulation and mycelial growth of Colletotrichum sp. (Wood and Holloman, 2003). Pyraclostrobin and Metiram inhibits the formation of ATP and stops hyphal tip growth and sporulation of Colletotrichum (Bartlet et al., 2002). The findings of current study could be strengthened by the research of (Rampersad and Teelucksingh, 2012) who observed minor mycelium growth of Colletotrichum under 
controlled environment applied with pyraclostrobin and metiram.

The second most effective fungicide was Nativo under controlled conditions as well as in the field. Nativo contains trifloxystrobin which has been applied to manage a broad array of plant diseases as it has wide range of antifungal properties (Reuveni, 2000). It kills the fungi by interrupting the electron transport chain, affecting the functioning of mitochondria and lowering respiration rate (Bartlett et al., 2002). Trifloxystrobin induces many changes in the physiology and metabolism of plants i.e. increased production of cytokinin which supports green pigments of leaves (Grossman and Retzlaff, 1997). It helps in disease management by reducing water loss under the biotic stress through the closure of stomata (Cho et al., 2008).

Melody Duo also controlled the C. graminicola and red leaf spot disease effectively. Melody Duo consists of iprovalicarb and proponeb that inhibits the colony growth of fungus by regulating polyketide synthesis (Hamada et al., 2014). It hinders the hyphal development and stops the formation of melanin in growth medium (Araki et al., 2015). After absorbing into leaves, iprovalicarb stimulates the systemic acquired resistance pathway subsequently results in minimum disease severity (Horvath and Chua, 1994). The fungicides having iprovaliacarb act by restricting melanin production of the fungi and stimulating the plant defense mechanism (Hagiwara et al., 2019). Propineb caused enhanced mortality of fungi at higher concentration in-vitro (Everett and Neilson, 1996). It interferes with the nucleic acid formation, amino acid production and other processes of the cell (Kimaru et al., 2018).

The use of Aliette also gave significant reduction in red lleaf spot disease severity. These results are also in confirmation with (Sitara and Akhtar, 2007) who ranked Aliette as the most effective fungicide against Colletrotrichum sp. than Mancozeb and other chemicals. There was low hyphal growth of Colletotrichum in growth medium that was mixed with Aliette, Mancozeb and Propineb at $1 \%$ concentration (Sitara and Hassan, 2007). Fosety-Al and Probineb has been widely used against Colletotrichum under in-vitro and in-vivo experiments (Gutierrez et al., 2006). Fosety-Al stimulates the PR proteins against the pathogenic attack and increases plant defense
(Chuang et al., 2003). Defense related activities of fosetyl-Al have also been studied by (Argelli et al., 2009). Minimum hyphal tip growth was recorded invitro when fungus was exposed to fungicide having fosetyl-Al (Amalfitano et al., 2000). As the red leaf spot disease affects the leaves of sorghum mainly, the reduced disease severity in Nativo (Fosetyl-Al) treated plants may be attributed by the altered leaf physiology (Cali, 2009).

\section{Conclusions and Recommendations}

Red leaf spot of sorghum is the most severe disease of sorghum crop in Pakistan caused by Colletotrichum graminicola. The four different fungicides were tested in the laboratory against Colletotrichum spp. The two fungicides Cabriotop and Nativo at 250ppm were best fungicides exhibited $88 \%$ and $78.1 \%$ growth inhibition of Colletotrichum spp as compared to Melody Duo and Aliette which showed $48.2 \%$ and $37.5 \%$ growth inhibition in in-vitro trail respectively. Whereas in in-vivo condition Cabrio Top and Nativo also showed the best result by controlling $74.57 \%$ and $71.52 \%$ respectively disease over control. While Melody Duo and Aliette were least effective by controlling $65.31 \%$ and $60.08 \%$ disease over control.

\section{Novelty Statement}

There is a very vast area of thirst in research on Red Leaf spot of sorghum. This study was firstly conducted to this economically important disease in Pakistan.

\section{Author's Contribution}

Misbah Ali: Conducted experiment.

Safdar Ali: Supervised the research trial.

Muhammad Ahmad Zeshan: Improved the scientific writing.

Rana Binyamin: Helped in literature review.

Nadeem Ahmed: Contributed in statistical analysis and data interpretation.

Muhammad Usman Ghani: Helped in experimental layout and spray formulations.

Awais Ahmed Khan: Contributed in data recording.

\section{Conflict of interest}

There is no conflict of interests regarding the publication of this article among the authors. 
Argelli, A.M., C.K. Wang and M.I. Clark. 2009. Effect of Fosetyl-A on the defense of plants. Phytobiol. Plant Protect. 12(3): 34-39.

Acharya, B., T.N.O. Quinn, W. Everman and H.L. Mehl. 2019. Effectiveness of fungicides and their application timing for the management of sorghum foliar anthracnose in the mid-atlantic United States. Plant Dis. 123(11): 2804-2811. https://doi.org/10.1094/PDIS-10-18-1867$\mathrm{RE}$

Amelework, B., H. Shimelis, P. Tongoona and M. Laing. 2015. Physiological mechanisms of drought tolerance in sorghum, genetic basis and breeding methods: A review. Afr. J. Agric. Res., 10: 3029-3040. https://doi.org/10.5897/ AJAR2015.9595

Amalfitano, C., A. Evidente, G. Surico, S. Tegli, E. Bertellli and L. Mugnai. 2000. Phenols and stilbene polyphenols in the wood of escadiseased grapevines. Phytopath. Medit., 39: 178-183.

Araki, N., R. Ezaki, T. Akase and N. Tomura. 2015. Studies on a novel fungicide tolprocarb: effects of tolprocarb against the life cycle of Magnaporthe oryzae. J. Phytopathol., 81: 252253.

Balba, H., 2007. Review of strobilurin fungicide chemicals. J. Environ. Sci. Health, 42: 441-451. https://doi.org/10.1080/03601230701316465

Balota, M., W.E. Thomason, H.L. Mehl, C.W. Cahoon, F. Reay-Jones, S.V. Taylor, M.L. Flessner and W. Everman. 2018. Revival of grain sorghum in the mid-Atlantic. Crops Soils, 51: 32-47. https://doi.org/10.2134/ cs2018.51.0110

Bartlett, D.W., J.M. Clough, J.R. Godwin, A.A. Hall, M. Hamer and B. Parr-Dobrzanski. 2002. The strobilurin fungicides. Pest. Manage. Sci. 58: 649-662. https://doi.org/10.1002/ps.520

Bertelsen, J.R., E.D. Neergaard and V. Smedegaard-Petersen. 2001. Fungicidal effects of azoxystrobin and epoxiconazole on phyllosphere fungi, senescence and yield of winterwheat. Plant Pathol.,50:190-205.https:// doi.org/10.1046/j.1365-3059.2001.00545.x

Brodribb, T.J. and N.M. Holbrook. 2004. Stomatal protection against hydraulic failure: A comparison of coexisting ferns and angiosperms. New Phytol., 162: 663- 8137.2004.01060.x

Cali, O.I., 2009. The effect of fosetyl-Al application on stomata in tomato (Lycopersicon esculentum Mill.) plant. J. Plant Breed. Crop Sci., 1: 45-48.

Chuang, H.W., T.F. Hisieh, M. Duval and T.L. Thomas. 2003. Genomic analysis of Arabidopsis gene expression in response to a systemic fungicide. In: Prade, R.A., Bohnert, H.J. (eds.), Genomics of plants and fungi, Marcel Dekker inc., New York, NY, USA. pp. 237-253. https:// doi.org/10.1201/9780203912249.ch7

Cho, S.M., B.R. Kang, S.H. Han, A.J. Anderson, J.Y. Park, Y.H. Lee, B.H. Cho, K.Y. Yang, C.M. Ryu and Y.C. Kim. 2008. 2R, 3R-butanediol, a bacterial volatile produced by Pseudomonas chlororaphis $\mathrm{O} 6$, is involved in induction of systemic tolerance to drought in Arabidopsis thaliana. Mol. Plant-Microbe Interact., 21: 1067-1075. https://doi.org/10.1094/MPMI21-8-1067

Crouch, J.A., L.P. Tredway, B.B. Clarke and B.I. Hillman. 2008. Phylogenetic and population genetic divergence corresponding with habitat for the pathogen Colletotrichum cereal and allied taxa across diverse grass communities. Mol. Ecol., 18: 123-135. https://doi.org/10.1111/ j.1365-294X.2008.04008.x

Erpelding, J.E. and L.K. Prom. 2004. Evaluation of Malian sorghum germplasm for resistance against anthracnose. Plant Path. J., 3(2): 65-71. https://doi.org/10.3923/ppj.2004.65.71

Everett, K.R. and H.F. Neilson. 1996. Evaluation of fungicides for control of Alternaria leaf spot of Pseudopanax. N. Z. J. Crop. Hortic. Sci., 24: 267-272. https://doi.org/10.1080/01140671.1 996.9513961

Fagan, E.B. D. Dourado Neto, R. Vivian, R.B. Franco, M.P. Yeda, L.F. Massignam, R.F.D. Oliveira and K.V. Martins. 2010. Effect of pyraclostrobin application on photosynthetic rate, respiration, nitrate reductase enzyme activity and soybean yield. Bragantia, 69: 771-777. https://doi.org/10.1590/S000687052010000400001

Grossmann, K. and G. Retzlaff. 1997. Bioregulatory effects of the fungicidal strobilurin kresoximmethyl in wheat (Triticum aestioum). Pest. Sci., 50: 11-20. https://doi.org/10.1002/ (SICI)1096-9063(199705)50:1<11::AID$\mathrm{PS} 556>3.0 . \mathrm{CO} ; 2-8$ 
Gutierrez, C.L., W. Ying, E. Lutton., K. Mcspaden and B.B. Gardener. 2006. Distribution and fungicide sensitivity of fungal pathogens causing anthracnose-like lesions on tomatoes grown on Ohio. Plant Dis., 90: 397. https://doi. org/10.1094/PD-90-0397

Gwary, D.M., D.M. Mailafiya and T.J. Jibrin. 2006. Survival of Colletotrichum sublineolum and other seed-borne fungi in sorghum seeds after twenty months of storage. Int. J. Agric. Biol., 8: 676679.

Gwary, D.M., N. Bwatanglang and B.S. Bdliya. 2008. Integrated management of sorghum anthracnose through the use of fungicides, crop varieties and manipulation of sowing dates in Sudan Savanna of Nigeria. Int. J. Agric. Biol. 10: 661-664.

Habib, N., A. Tahir and Q. Ain. 2013. Current situation and future outlook of sorghum and production in Pakistan. Asian J. Agric., 3(5): 283-289.

Hagiwara, H., R. Ezaki, T. Hamada, M. Tsuda and K. Ebihara. 2019. Development of a novel fungicide, toplocarb. J. Pest. Sci., 44(3): 208213. https://doi.org/10.1584/jpestics.J19-01

Hamada, T., M. Asanagi, T. Satozawa, N. Araki, S. Banba, N. Higashimura, T. Akase and K. Hirase. 2014. Action mechanism of the novel rice blast fungicide tolprocarb distinct from that of conventional melanin biosynthesis inhibitors. J. Pestic. Sci., 39: 152-158. https:// doi.org/10.1584/jpestics.D14-033

Hermes, S., K. Seehaus, H. Koehle and U. Conrath. 2002. A strobilurin fungicide enhances the resistance of tobacco against tobacco mosaic virus and Psedomonas syringae pv tabaci. Plant Physiol., 130: 120-127. https://doi. org/10.1104/pp.004432

Horvath, D. and N. Chua. 1994. The role of salicylic acid in systemic acquired resistance. Curr. Opin. Biotechnol., 5: 131-136. https://doi. org/10.1016/S0958-1669(05)80025-4

John, R.N., T. Tilman, J. Schoberb and S.R. Beanb. 2006. Novel food and non-food uses for sorghum and millets. J. Cereal Sci., 44: 252271. https://doi.org/10.1016/j.jcs.2006.06.009

Kanungo, M. and J. Joshi. 2014. Impact of Pyraclostrobin (F-500) on crop plants. Plant Sci. Today, 1(3): 174-178. https://doi. org/10.14719/pst.2014.1.3.60

Kimaru, S.K., E. Monda, R.C. Cheruiyot, J.
Mbaka and A. Alakonya. 2018. Sensitivity of Colletotrichum gloeosporides isolates from diseased avocado fruits to selected fungicides in Kenya. Adv. Agric., https://doi. org $/ 10.1155 / 2018 / 3567161$

Li, Y. and D.O. TeBeest. 2009. Temporal and spatial development of sorghum anthracnose in Arkansas. Plant Dis., 93: 287-292. https://doi. org/10.1094/PDIS-93-3-0287

Lima, J.D., Wd. S. Moraes, M.G. da Silva and S. Helena. 2012. Physiological responses in banana seedlings treated with strobilurins. Semina: Agric. Sci., 33: 77-85. https://doi. org/10.5433/1679-0359.2012v33n1p77

Logan, B.A., W.W. Adams and B. DemmigAdams. 2007. Viewpoint: Avoiding common pitfalls of chlorophyll fluorescence analysis under field conditions. Funct. Plant Biol., 34: 853-859. https://doi.org/10.1071/FP07113

Marley, P.S., R.P. Thakur and O. Ajayi. 2001. Variation among foliar isolates of Colletotrichum sublineolum of sorghum in Nigeria. Field Crops Res., 69: 133-142. https://doi.org/10.1016/ S0378-4290(00)00128-3

Marley, P.S., 2004. Effects of integrating host plant resistance with time of planting or fungicides on anthracnose and grain mould and yield of sorghum (Sorghum bicolor) in the Nigerian northern Guinea Savanna. J. Agric. Sci., 142: 345-350. https://doi.org/10.1017/ S0021859604004277

Mishra, S.R., 2005. Plant protection and pest management. Discovery Publishing House Pvt. Ltd. New Delhi, India.

Ngugi, H.K., A.M. Julian, S.B. King and B.J. Peacocke. 2000. Epidemiology of sorghum anthracnose (Colletotrichum sublineolum) and leaf blight (Exserobilum turcicum) in Kenya. Plant Pathol., 49: 129-140. https://doi. org/10.1046/j.1365-3059.2000.00424.x

Pinto, N.F.J.A., 2003. Chemical control of the anthracnose (Colletotrichum graminicola) of sorghum. Rev. Bras. Milho. Sorgo Brazil, 2: 148-152.https://doi.org/10.18512/1980-6477/ rbms.v2n3p148-152

Rampersad, S.N., and L.D. Teelucksingh. 2012. Differential responses of Colletotrichum gloeosporioides and C. truncatum isolates from different hosts to multiple fungicides based on two assays. Plant Dis., 96: 1526-1536. https:// doi.org/10.1094/PDIS-10-11-0906-RE 
Reuveni, M., 2000. Efficacy of trifloxystrobin (Flint): A new strobilurin fungicide, in controlling powdery mildews on apple, mango and nectarine, and rust on prune trees. Crop Prot., pp. 335-341. https://doi.org/10.1016/ S0261-2194(00)00026-0

Silva, D.D., C.R. Casela, H.A. Castro, F.G. Santos and A.S. Ferreira. 2008. Diversidade populacional de Colletotrichum sublineolum em seis localidades no Brasil. Summa Phytopath., 34: 149-155. https://doi.org/10.1590/S010054052008000200007

Sitara, U. and N. Hassan. 2007. Studies on the efficacy of chemicals and non-chemicals treatments to control mycoflora associated with chili seed. Pak. J. Bot., 43: 95-100.

Sitara, U. and S.Akhter.2008. Efficacy of fungicides, sodium hypochlorite and neem seed powder to control seed borne pathogens of maize. Pak. J. Bot., 39: 285-292.

Swoboda, C. and P. Pedersen. 2009. Effect of fungicide on soybean growth and yield. Agron.
J., 101: 352-356. https://doi.org/10.2134/ agronj2008.0150

Steel, R.G.D., J.H. Torrie and D.A. Dicky. 1997. Principles and procedures of statistics. A biometrical approach, $3^{\text {rd }}$ Ed. McGraw Hill Book Co. Inc., New York.

Tesso, T., R. Perumal, G.L. Radwan, C.R. Little, L.K. Pro, A. Adeyanju and C.W. Magill. 2012. Sorghum pathology and biotechnology-A fungal disease perspective: Part II. Anthracnose, stalk rot, and downy mildew. Eur. J. Plant Sci. Biotech., 6: 31-44.

Thakur, R.P. and K. Mathur. 2000. Anthracnose. Compendium of Sorghum diseases. Frederiksen, R.A., and Odvody, G. N., eds. Am. Phytopathol. Soc., St. Paul, MN. pp. 10-12.

Wood, P.M., and D.W. Holloman. 2003. Review: A critical evaluation of the role of alternative oxidase in the performance of strobilurin and related fungicides acting at the Qo site of complex III. Pest Manage. Sci., 59: 499-511. https://doi.org/10.1002/ps.655 